\title{
Cultural Competence in Nursing and Its Impact on the Quality of Care for Patients from Culturally Diverse Groups: A Systematic Literature Review
}

\author{
Sabina Ličen \\ University of Primorska, Slovenia \\ sabina.licen@fvz.upr.si \\ Igor Karnjuš \\ University of Primorska, Slovenia \\ igor.karnjus@fvz.upr.si \\ Urška Bogataj \\ University of Primorska, Slovenia \\ urska.bogataj@fvz.upr.si \\ Doroteja Rebec \\ University of Primorska, Slovenia \\ doroteja.rebec@fvz.upr.si

\section{Mirko Prosen} \\ University of Primorska, Slovenia \\ mirko.prosen@fvz.upr.si
}

The growth of culturally diverse segments of the population in Slovenia means the need for culturally competent nurses has never been greater. Cultural competence has already been a topic of interest for several years among all healthcare provider groups. In Slovenia, however, the effect of culturally competent nursing on the quality of care for patients from culturally diverse groups has never been systematic reviewed. A review of the literature was conducted in May 2018 to identify the evidence available on the effectiveness of culturally competent nursing on the quality of care. Based on the research purpose, terms combining Medical Subject Headings (MeSH), phrases, as well as free text or keywords were searched for. The literature published between 2000 and 2018 was extracted and a sample of 533 papers was obtained. Four studies meeting the criteria were finally included in the qualitative analysis. Two studies revealed that the effectiveness of cultural training is shown in increased patient self-care behaviours, a higher level of social functioning and improved overall functional capacity. The two other studies used in our study did not describe patient outcomes as they mainly looked at improvements in cultural competency among nurses. Our review shows several important considerations for future research and supports calls for greater methodological rigour in studies of cultural competence education for health professionals. 


\section{Introduction}

Demographic changes in the Slovenian population over the decades have transformed the country into a multicultural society. The war in different parts of former Yugoslavia in 1991 triggered the first major migration flows of people from the former republics (especially Bosnia and Herzegovina, Macedonia, Serbia and Kosovo). Even today, these migration flows represent the highest number of foreign immigrants in Slovenia.' Further, estimates show that approximately 1.9 million people from non-EU countries immigrated to the European Union in 2014. These figures all show that immigrant is both growing and altering the population structure of the European Union, suggesting the need for education in transcultural nursing to ensure nurses are able to provide culturally competent care (Ličen, Karnjuš, \& Prosen, 2017). Transcultural nursing is an essential aspect of today's healthcare and represents both a speciality and a general practice area. It focuses on worldwide cultures and comparative cultural caring, health and nursing phenomena. Established as a formal area of inquiry and practice more than 40 years ago, transcultural nursing's goal is to provide culturally congruent care (Truong, Paradies, \& Priest, 2014). Nurses must acquire the necessary knowledge and skills in cultural competency since culturally competent nursing care helps ensure patient satisfaction and positive outcomes (Maier-Lorentz, 2008).

There are as many varying definitions for the term cultural competence as there are for the term culture. Culture can be defined as the learned and shared knowledge and symbols that specific groups use to interpret their experience of reality and to guide their thinking and behaviour (Prosen, 2015). Thus, cultural competence can be defined as a continual process of striving to become increasingly self-aware, to value diversity and to become knowledgeable about cultural strengths (Bonecutter \& Gleeson, 1997). Cultural competence may be defined in various ways but it is usually understood as possessing the attitudes, knowledge and skills necessary for providing quality care to a diverse population; in other words, the capacity to deliver culturally appropriate care. However, according to Leininger $(2002,1999)$, the term cultural competence was first coined by her in the 1960 s as part of her theory of cultural care diversity and universality.

Embedding cultural competence in healthcare systems enables systems to provide appropriate care to patients with a range of values, beliefs and behaviours, including meeting patients' social, cultural and linguistic needs (Horvat, Horey, Romios, \& Kis-Rigo, 2014). The cultural competence in the

\footnotetext{
${ }^{1}$ See https://emm.si/en/migration-and-slovenia.
} 
healthcare paradigm commits healthcare organisations, institutions and professionals to understand and respect cultural differences, and adjust their care accordingly. The leading concept of cultural competence in healthcare integrates three fundamental components: linguistic competence, workforce diversity, and workforce cultural competence (Baldwin, 2003; Gallagher \& Polanin, 2015). At this point, we can conclude that cultural competency is a broad concept used to describe a variety of interventions that aim to improve the accessibility and effectiveness of healthcare services for people from culturally diverse groups (Truong et al., 2014).

Today, it is well known that nurses who provide culturally competent nursing hold the potential to improve the quality of care and improve patient satisfaction, therefore leading to better health outcomes for culturally diverse groups (Gallagher \& Polanin, 2015; Waite \& Calamaro, 2010). In Slovenia, the effect of culturally competent nursing on the quality of care for patients from culturally diverse groups has never been systematically reviewed. On the other hand, some foreign studies have evaluated the effects of training interventions in cultural competence. The learning activities and length of the interventions varied, and the most common target learners were nursing and medical students (Beach et al., 2005; Peña Dolhun, Muñoz, \& Grumbach, 2003; Price et al., 2005). Further, scientific evidence suggests a significant correlation between the cultural and linguistic competencies of healthcare providers and improved patient nursing outcomes (Betancourt, Green, Carrillo, \& Ananeh-Firempong, 2003).

What emerges from the literature is training in cultural competence may be an effective way to support nurses in their clinical work and therefore an important area to study. For these reasons, this systematic review aimed to evaluate the literature on the ways effective cultural competence training for nurses improves cultural competency and determine whether professionals undergoing such training increased the quality of their care given to patients from culturally diverse groups.

\section{Methodology}

A systematic literature review was conducted to address the question: 'How effective is non-formal training for nurses on culturally competent healthcare for improving the quality of care for patients from culturally diverse groups?'

\section{Search Strategy}

A review of the literature was conducted in May 2018 to identify available evidence on how culturally competent nursing impacts the quality of care 
of patients from culturally diverse groups. A search was conducted using online bibliographic databases such as PubMed, CINAHL and ScienceDirect. For the search terms, a combination of the following Medical Subject Headings (MeSH): 'transcultural nursing,' 'culturally competent care,' 'cultural competency,' 'cultural diversity,' 'cultural competence training,' 'cultural sensitivity training' and 'education, nursing' was used. The search was performed using the following keywords in English with Boolean operators 'and' and 'or.'

\section{Study Selection}

A search was undertaken in each database and, to further the research's relevance, literature published between January 2000 and May 2018 was considered. A sample of 533 papers was obtained. The titles and abstracts were screened by the authors, duplicates were removed and the inclusion criteria (English language, full-text availability, and primary study in a peer-reviewed journal) were applied. After the removal of duplicates, 69 articles were left, of which a further 64 were then excluded due to inadequately meeting the inclusion criteria. Four studies satisfying the criteria were finally included in the qualitative analysis.

A systematic review of literature on the effect of culturally competent nursing on the quality of care for patients from culturally diverse groups was conducted according to the Preferred Reporting Items for Systematic Reviews and Meta-Analyses (PRISMA), using the PRISMA checklist and the PRISMA flowchart methodology (Moher, Liberati, Tetzlaff, Altman, \& PRISMA Group, 2009). The PRISMA flow diagram (Figure 1) summarises the article selection process.

\section{Results}

The final four studies identified in the current review were (listed in order of publication): (1) (Majumdar, Browne, Roberts, \& Carpio, 2004); (2) (McElmurry et al., 2009); (3) (Berlin, Nilsson, \& Törnkvist, 2010); and (4) (Chapman, Martin, \& Smith, 2014). These studies varied in their stated aims, settings, participants and how they were described, interventions and the outcomes measured. Data extraction included author/year, country where the research was conducted, study aim, study design, and descriptions of patients involved in the study (Table 1).

\section{Description of the Interventions}

Competence training for health professionals generally includes components such as cultural awareness, cultural knowledge and cultural skills (Sue, 
Table 1 Comparison of Study Aims, Settings and Descriptions of Patients

\begin{tabular}{|c|c|c|c|c|}
\hline Author/Year & Country & Study aim & Study design & Patient descriptions \\
\hline $\begin{array}{l}\text { Berlin et al. } \\
(2010)\end{array}$ & Sweden & $\begin{array}{l}\text { To evaluate the ex- } \\
\text { tent to which spe- } \\
\text { cific training affected } \\
\text { how nurses rated } \\
\text { their own cultural } \\
\text { competence, diffi- } \\
\text { culties, and concerns } \\
\text { and to study how } \\
\text { nurses evaluated the } \\
\text { training }\end{array}$ & $\begin{array}{l}\text { The study partici- } \\
\text { pants were an inter- } \\
\text { vention group and } \\
\text { a control group of } \\
\text { nurses working in } \\
\text { health services in } \\
\text { the Stockholm and } \\
\text { Sörmlands coun- } \\
\text { ties. The clinical part } \\
\text { of these services is } \\
\text { provided at primary } \\
\text { child healthcare cen- } \\
\text { tres. }\end{array}$ & $\begin{array}{l}\text { Of the } 39 \text { municipal- } \\
\text { ities in Stockholm } \\
\text { County, } 27 \text { had reg- } \\
\text { istered a having at } \\
\text { least } 20 \% \text { of the chil- } \\
\text { dren with immigrant } \\
\text { parents. Fifteen of } \\
\text { those municipalities } \\
\text { were randomly cho- } \\
\text { sen. }\end{array}$ \\
\hline $\begin{array}{l}\text { Chapman } \\
\text { et al. (2014) }\end{array}$ & Australia & $\begin{array}{l}\text { To determine if an } \\
\text { accredited cultural } \\
\text { awareness training } \\
\text { programme affected } \\
\text { emergency depart- } \\
\text { ment staff knowl- } \\
\text { edge, familiarity, at- } \\
\text { titude of and percep- } \\
\text { tion regarding Aus- } \\
\text { tralian Aboriginal } \\
\text { and Torres Strait Is- } \\
\text { lander people }\end{array}$ & $\begin{array}{l}\text { Group pre-test/post- } \\
\text { test intervention de- } \\
\text { sign involved mea- } \\
\text { suring staff cultural } \\
\text { awareness before } \\
\text { and after training }\end{array}$ & $\begin{array}{l}\text { Aboriginal and Tor- } \\
\text { res Strait Islander } \\
\text { people }\end{array}$ \\
\hline $\begin{array}{l}\text { Majumdar } \\
\text { et al. (2004) }\end{array}$ & Canada & $\begin{array}{l}\text { To determine the } \\
\text { effectiveness of } \\
\text { cultural sensitiv- } \\
\text { ity training on the } \\
\text { knowledge and atti- } \\
\text { tudes of healthcare } \\
\text { providers, and to as- } \\
\text { sess the satisfaction } \\
\text { and health outcomes } \\
\text { of patients from dif- } \\
\text { ferent culturally di- } \\
\text { verse groups with } \\
\text { healthcare providers } \\
\text { who received train- } \\
\text { ing }\end{array}$ & $\begin{array}{l}\text { In a randomised } \\
\text { controlled trial, } 114 \\
\text { healthcare providers } \\
\text { (nurses and home- } \\
\text { care workers) and } 133 \\
\text { patients (from two } \\
\text { community agen- } \\
\text { cies and one hospi- } \\
\text { tal) were randomly } \\
\text { assigned to experi- } \\
\text { mental (training) and } \\
\text { control groups and } \\
\text { were followed for } 18 \\
\text { months }\end{array}$ & $\begin{array}{l}\text { Most participants } \\
\text { were either Roman } \\
\text { Catholic or Protes- } \\
\text { tant. Although all } \\
\text { participants spoke } \\
\text { English, a small } \\
\text { share (below } 15 \% \text { for } \\
\text { both groups) spoke } \\
\text { French as their na- } \\
\text { tive language. }\end{array}$ \\
\hline $\begin{array}{l}\text { McElmurry } \\
\text { et al. (2009) }\end{array}$ & USA & $\begin{array}{l}\text { To improve diabetes } \\
\text { care among limited } \\
\text { English-proficient } \\
\text { Latino patients }\end{array}$ & $\begin{array}{l}\text { Health promoters } \\
\text { served a total of } \\
1,994 \text { Latino diabetes } \\
\text { patients, providing a } \\
\text { total of } 4,242 \text { patients }\end{array}$ & $\begin{array}{l}\text { Latino diabetes pa- } \\
\text { tients }\end{array}$ \\
\hline
\end{tabular}




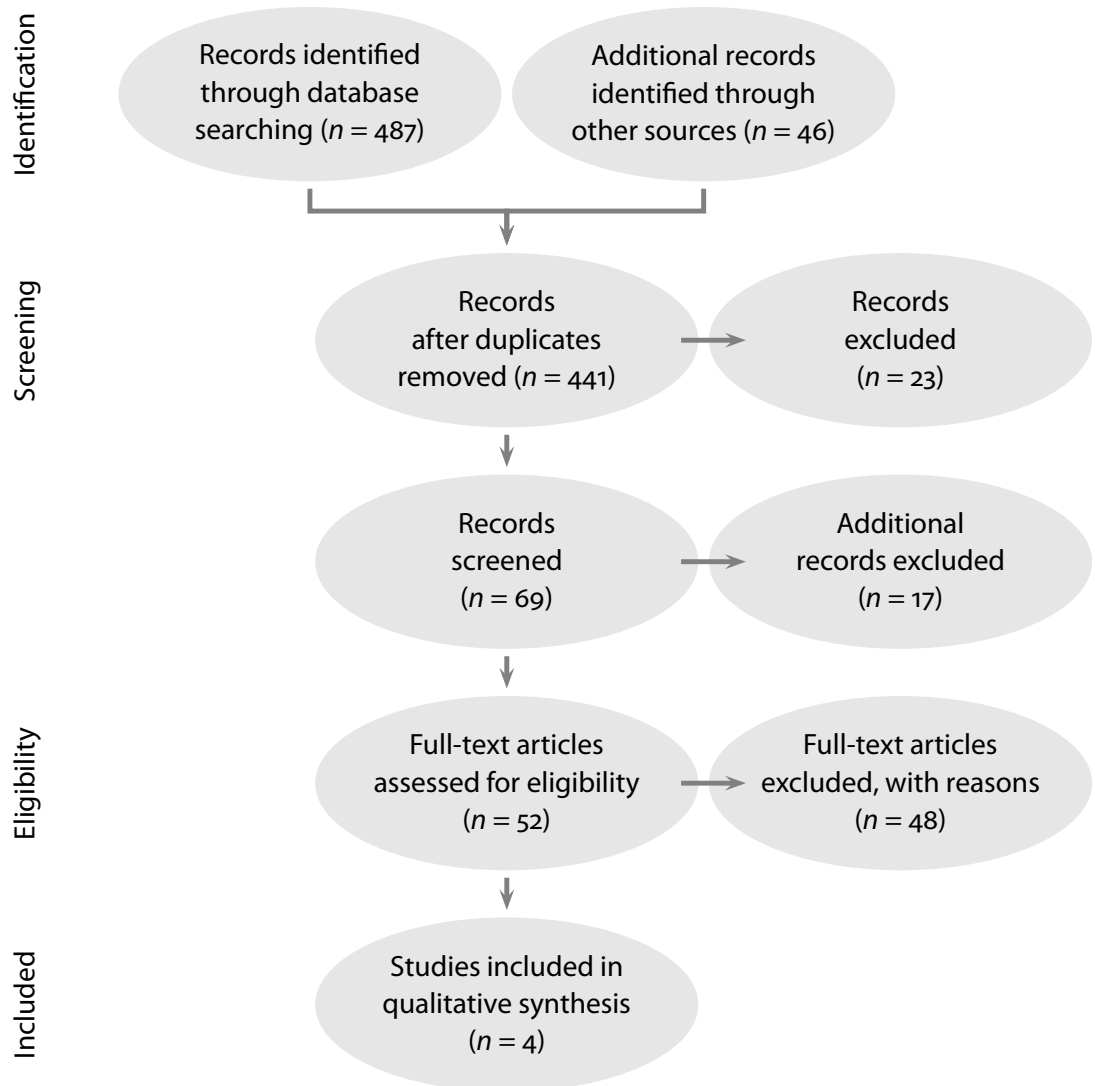

Figure 1 Presentation of the Selection Process through the PRISMA Flow Diagram

Zane, Nagayama Hall, \& Berger, 2009). Teaching and learning methods and the content of cultural competence in education interventions range from simple approaches that specify aspects of cultural self-awareness and intercultural communication skills to more complex understandings that show a deeper analysis of socio-cultural barriers to healthcare at the clinical, organisational level and structural levels (Betancourt et al., 2003). After reviewing the literature, a conceptual framework derived from a synthesis of key cultural competence models and educational intervention frameworks is suggested to ensure a consistent approach to describing and assessing the interventions. A conceptual framework (Table 2) comprises three domains that describe the core ingredients of cultural competence education/training interventions. 
Table 2 Conceptual Framework

\begin{tabular}{lll}
\hline Educational content & Pedagogical approach & Structure of the intervention \\
\hline Types of knowledge & Teaching and learning & Delivery and format \\
Skills & method & Frequency and timing \\
& Theoretical constructs and \\
principles & $\begin{array}{l}\text { Assessment and evaluation } \\
\text { of intervention }\end{array}$ \\
\hline
\end{tabular}

There was considerable heterogeneity in the stated purpose, content, duration and nature of the interventions assessed in each study. A summary of the interventions derived from the four studies identified is shown in Tables 3-6.

Table 3 Summary of the Interventions: Educational Content - Types of knowledge

\begin{tabular}{|c|c|c|c|c|}
\hline Item & $\begin{array}{l}\text { Berlin et al. } \\
(2010)\end{array}$ & $\begin{array}{l}\text { Chapman et al. } \\
(2014)\end{array}$ & $\begin{array}{l}\text { Majumdar et al. } \\
(2004)\end{array}$ & $\begin{array}{l}\text { McElmurry et al. } \\
(2009)\end{array}$ \\
\hline $\begin{array}{l}\text { Culture/cultural } \\
\text { competence }\end{array}$ & $\begin{array}{l}\text { Cultural compe- } \\
\text { tency }\end{array}$ & $\begin{array}{l}\text { Cultural aware- } \\
\text { ness }\end{array}$ & $\begin{array}{l}\text { Cultural sensitiv- } \\
\text { ity }\end{array}$ & $\begin{array}{l}\text { Cultural compe- } \\
\text { tency }\end{array}$ \\
\hline $\begin{array}{l}\text { Socio-cultural } \\
\text { context of } \\
\text { health dispari- } \\
\text { ties }\end{array}$ & $\begin{array}{l}\text { Contribution to } \\
\text { improved qual- } \\
\text { ity of health ser- } \\
\text { vices, with re- } \\
\text { duced risk of } \\
\text { healthcare dis- } \\
\text { parities among } \\
\text { children of im- } \\
\text { migrant parents }\end{array}$ & Not reported & Not reported & $\begin{array}{l}\text { Bridges to } \\
\text { Health pro- } \\
\text { gramme to im- } \\
\text { prove care and } \\
\text { reduce health } \\
\text { disparities }\end{array}$ \\
\hline $\begin{array}{l}\text { Epidemiology } \\
\text { and social deter- } \\
\text { minants }\end{array}$ & Not reported & Not reported & Not reported & $\begin{array}{l}\text { Latino diabetes } \\
\text { patients }\end{array}$ \\
\hline $\begin{array}{l}\text { Constructs of } \\
\text { racism and prej- } \\
\text { udice }\end{array}$ & $\begin{array}{l}\text { Training in- } \\
\text { cluded new } \\
\text { knowledge } \\
\text { about experi- } \\
\text { ences of being } \\
\text { different, ethno- } \\
\text { centrism and on } \\
\text { racism and prej- } \\
\text { udice }\end{array}$ & Not reported & Not reported & Not reported \\
\hline $\begin{array}{l}\text { Specific theoret- } \\
\text { ical models }\end{array}$ & $\begin{array}{l}\text { Campinha- } \\
\text { Bacote's defini- } \\
\text { tion and cultural } \\
\text { competence } \\
\text { model }\end{array}$ & Not reported & Not reported & Not reported \\
\hline
\end{tabular}


Table 4 Summary of the Interventions: Educational Content - Skills

\begin{tabular}{|c|c|c|c|c|}
\hline Item & $\begin{array}{l}\text { Berlin et al. } \\
(2010)\end{array}$ & $\begin{array}{l}\text { Chapman et al. } \\
\text { (2014) }\end{array}$ & $\begin{array}{l}\text { Majumdar et al. } \\
(2004)\end{array}$ & $\begin{array}{l}\text { McElmurry et al. } \\
(2009)\end{array}$ \\
\hline $\begin{array}{l}\text { Cultural self- } \\
\text { assessment }\end{array}$ & Unclear & Not reported & $\begin{array}{l}\text { Cultural Self- } \\
\text { Awareness } \\
\text { Questionnaire } \\
\text { and the Dog- } \\
\text { matism Scale in- } \\
\text { struments }\end{array}$ & Not reported \\
\hline $\begin{array}{l}\text { Communication, } \\
\text { collaboration } \\
\text { and non-verbal } \\
\text { communication }\end{array}$ & $\begin{array}{l}\text { Training in- } \\
\text { cluded skills in } \\
\text { different com- } \\
\text { munication } \\
\text { styles and bar- } \\
\text { riers to intercul- } \\
\text { tural communi- } \\
\text { cation }\end{array}$ & Not reported & Not reported & $\begin{array}{l}\text { Spanish im- } \\
\text { mersion pro- } \\
\text { gramme, Span- } \\
\text { ish language } \\
\text { classes, and cul- } \\
\text { tural workshops }\end{array}$ \\
\hline $\begin{array}{l}\text { Deconstructing } \\
\text { stereotypes }\end{array}$ & $\begin{array}{l}\text { Face-to-face cul- } \\
\text { tural interac- } \\
\text { tions with clients } \\
\text { from different } \\
\text { cultural back- } \\
\text { grounds, trying } \\
\text { to modify exist- } \\
\text { ing beliefs, or to } \\
\text { prevent the pos- } \\
\text { sible stereo- typ- } \\
\text { ing of these indi- } \\
\text { viduals }\end{array}$ & Unclear & Unclear & Unclear \\
\hline
\end{tabular}

\section{Patient Outcomes}

- McElmurry et al. (2009). To assess the outcomes of certain patientdirected interventions, data from patient encounter forms were analysed using frequencies, correlations, paired t tests, and logistic regression. Their analysis of the available data (for the 392 patients for whom data were available who had two health-promoter encounters at least 30 days or more apart; range $=30$ days to $>1$ year) revealed that limited English-proficient Latino diabetes patients who received healthpromoter services demonstrated improvement in blood glucose control as measured by a drop in percentage of $\mathrm{HbA1c}$. For these $392 \mathrm{pa-}$ tients, their mean drop in $\mathrm{HbA}_{1} \mathrm{c}$ from 9.65 to 8.61 was statistically significant (paired $t$-test, $t=-8.5344, p<0.001$ ). It follows that the healthpromoter intervention was associated with enhanced access to care, 
Table 5 Summary of the Interventions: Pedagogical Approach

\begin{tabular}{lllll}
\hline Item & $\begin{array}{l}\text { Berlin et al. } \\
(\text { 2010) }\end{array}$ & $\begin{array}{l}\text { Chapman et al. } \\
(2014)\end{array}$ & $\begin{array}{l}\text { Majumdar et al. } \\
(2004)\end{array}$ & $\begin{array}{l}\text { McElmurry et al. } \\
(2009)\end{array}$ \\
\hline $\begin{array}{l}\text { Teaching and } \\
\text { learning method }\end{array}$ & $\begin{array}{l}\text { A participatory } \\
\text { learning ap- } \\
\text { proach, link- } \\
\text { ing theory to } \\
\text { practice, case } \\
\text { methodology, } \\
\text { specific study } \\
\text { derived from } \\
\text { previous re- } \\
\text { search }\end{array}$ & $\begin{array}{l}\text { Cultural aware- } \\
\text { ness training }\end{array}$ & & $\begin{array}{l}\text { Spanish lan- } \\
\text { guage skills and } \\
\text { cultural compe- } \\
\text { tency training } \\
\text { for healthcare } \\
\text { providers }\end{array}$ \\
& & & \\
\hline $\begin{array}{l}\text { Key theoretical } \\
\text { construct and } \\
\text { principles }\end{array}$ & $\begin{array}{l}\text { Campinha- } \\
\text { Bacote's cultural } \\
\text { competence } \\
\text { model }\end{array}$ & Not reported & Unclear & Not reported \\
\hline
\end{tabular}

increased patient self-care behaviours, and improved blood glucose control.

- Majumdar et al. (2004) No statistically significant differences in mean scores were found between patients in the control and experimental groups in relation to 'client satisfaction,' 'mental health,' 'physical health,' and 'activities of daily living.' In addition, patients of mostly European and British origin who received care from providers trained in cultural sensitivity had a higher level of social functioning and improved overall functional capacity without a significant increase in healthcare expenditures, after 1.5 years.

The two other studies used in our study did not describe patient outcomes. They mainly described improvements in cultural competency among nurses.

- Berlin et al. (2010). The authors report the training may have had positive effects on the nurses' working conditions as they rated it to have impacted their ability to cope with the demands of their work tasks in the health services. These effects are presumed to contribute to improved quality health services, with a reduced risk of healthcare disparities among the children of immigrant parents.

- Chapman et al. (2014). This study shows that cultural awareness training, given in staggered sessions over six weeks, changed the perception of emergency healthcare workers towards Aboriginal and Torres Strait Islander people, but did not affect their attitude to them. 
Table 6 Summary of the Interventions: Structure

\begin{tabular}{|c|c|c|c|c|}
\hline Item & Berlin et al. (2010) & $\begin{array}{l}\text { Chapman et al. } \\
\text { (2014) }\end{array}$ & $\begin{array}{l}\text { Majumdar et } \\
\text { al. (2004) }\end{array}$ & $\begin{array}{l}\text { McElmurry et al. } \\
(2009)\end{array}$ \\
\hline Delivery & Face-to-face & Face-to-face & Unclear & Unclear \\
\hline Format & $\begin{array}{l}\text { Over } 4 \text { weeks of } \\
\text { clinical work and } \\
\text { in at least one } \\
\text { case, nurses were } \\
\text { instructed to con- } \\
\text { sider direct face- } \\
\text { to-face cultural } \\
\text { interactions by } \\
\text { using the study- } \\
\text { specific theoreti- } \\
\text { cal models }\end{array}$ & $\begin{array}{l}\text { Face-to-face in- } \\
\text { struction, case } \\
\text { studies, interac- } \\
\text { tive activities, } \\
\text { group discussions } \\
\text { and personal re- } \\
\text { flection }\end{array}$ & Unclear & $\begin{array}{l}\text { Interventions: } \\
\text { Spanish immer- } \\
\text { sion programme, } \\
\text { Spanish language } \\
\text { classes, and cultural } \\
\text { workshops }\end{array}$ \\
\hline $\begin{array}{l}\text { Frequency } \\
\text { and duration }\end{array}$ & $\begin{array}{l}\text { Training lasted for } \\
3 \text { days, with the } \\
\text { third day coming } \\
\text { after } 4 \text { weeks of } \\
\text { clinical work at } \\
\text { health centres }\end{array}$ & $\begin{array}{l}\text { The cultural } \\
\text { awareness train- } \\
\text { ing was delivered } \\
\text { in six weeks and } \\
\text { consisted of three } \\
\text { 2-hour workshops }\end{array}$ & $\begin{array}{l}36 \text { hours of } \\
\text { cultural sen- } \\
\text { sitivity train- } \\
\text { ing }\end{array}$ & 3-year period \\
\hline $\begin{array}{l}\text { Method of } \\
\text { assessment }\end{array}$ & $\begin{array}{l}\text { The Clinical Cul- } \\
\text { tural Compe- } \\
\text { tence Training } \\
\text { Questionnaire- } \\
\text { pre and the Clini- } \\
\text { cal Cultural Com- } \\
\text { petency Train- } \\
\text { ing Evaluation } \\
\text { Questionnaire- } \\
\text { post }\end{array}$ & $\begin{array}{l}\text { 'Area human re- } \\
\text { sources develop- } \\
\text { ment/population } \\
\text { health survey of } \\
\text { participation in } \\
\text { Aboriginal aware- } \\
\text { ness training } \\
\text { workshop' tool }\end{array}$ & Unclear & $\begin{array}{l}\text { Assessment instru- } \\
\text { ment used to assess } \\
\text { patients' knowl- } \\
\text { edge of diabetes } \\
\text { and its manage- } \\
\text { ment. Health pro- } \\
\text { moters received ori- } \\
\text { entation to the clin- } \\
\text { ical site, assessment } \\
\text { of knowledge com- } \\
\text { petency, and ongo- } \\
\text { ing supervision and } \\
\text { in-service training }\end{array}$ \\
\hline $\begin{array}{l}\text { Evaluation } \\
\text { method }\end{array}$ & Unclear & Not reported & Unclear & $\begin{array}{l}\text { A combination of } \\
\text { open-ended ques- } \\
\text { tions in written } \\
\text { evaluations of both } \\
\text { the Spanish immer- } \\
\text { sion programme } \\
\text { and cultural work- } \\
\text { shops and pre- and } \\
\text { post-immersion } \\
\text { programme focus } \\
\text { groups with pro- } \\
\text { gramme partici- } \\
\text { pants }\end{array}$ \\
\hline
\end{tabular}




\section{Discussion}

There is a deficit of studies on changes in nurses' knowledge and behaviour in the area of cultural competence and subsequent impacts on patient outcomes. The four reviewed studies focused on different types of intervention, different targeted groups in various settings and measured dissimilar outcomes. This heterogeneity in intervention strategies and how they are implemented makes it difficult to offer empirical evidence on their effectiveness on the quality of care for patients from culturally diverse groups. However, despite some methodological limitations of the four studies included, this review contains the available evidence on interventions used with the aim to improve cultural competence among nurses working with patients from culturally diverse groups.

It has been shown that various forms of cultural training improve the cultural competence of nurses (Govere \& Govere, 2016). The general focus of cultural competence interventions has been on educating and training nurses, like other healthcare workers, in the knowledge, attitudes and skills needed to effectively respond to socio-cultural issues arising in clinical encounters (Betancourt et al., 2003). Cultural competence training can include: understanding the central role of culture in all lives and how it shapes behaviour; respect and acceptance of cultural differences; learning to effectively utilise culturally adapted and culturally specific practices; and, continuous development of healthcare employees' awareness of personal cultural influences and prejudices (Jongen, McCalman, \& Bainbridge, 2018; Warren, 2002).

Intervention strategies in the reviewed studies showed some evidence of their effectiveness, although there is limited research revealing a positive relationship between cultural competency training and improved patient outcomes. While cultural competency training is an important component of an overall framework for cultural competence, it is generally insufficient to merely change health professionals' behaviour if we wish to influence patient-related outcomes such as patient satisfaction, adherence and health outcomes (Beach et al., 2005; Lie, Lee-Rey, Gomez, Bereknyei, \& Braddock, 2011). Improving patient-related outcomes based on cultural competency training requires structural changes at the level of the organisation (Betancourt et al., 2003; Clifford, McCalman, Bainbridge, \& Tsey, 2015). Further, building up the cultural competence of healthcare professionals and organisations may be one of the best strategies for narrowing healthcare disparities. Although there is some evidence that organisations which have integrated cultural competency standards into policies and practices influ- 
ence health professionals to develop more culturally competent behaviours, more methodologically rigorous research is needed in this area (Paez, Allen, Carson, \& Cooper, 2008). The fact is that cultural competence continues to be developed as a major strategy to address health inequities. We identified four studies assessing the effects of cultural competence education/training for health professionals on patient-related outcomes.

\section{Conclusions}

The four studies included in the final analysis showed some degree of effectiveness regarding patient-related outcomes or nurses' acquisition of cultural competencies. They differed in their experimental designs, intervention and patient participants, and intervention treatments (e.g., cultural competence training content, duration, and methods). The results of this review suggest that the evidence found in published evaluations is still insufficient to allow any conclusions on which intervention strategies are the most effective for improving cultural competency in healthcare. Attempts to improve the cultural competence of health professionals should continue and educators and researchers should evaluate these interventions in methodologically rigorous research.

\section{References}

Baldwin, D. M. (2003). Disparities in health and health care: Focusing efforts to eliminate unequal burdens. Online Journal of Issues in Nursing, 8(1), 2. Retrieved from http://www.ncbi.nlm.nih.gov/pubmed/12729451

Beach, M. C., Price, E. G., Gary, T. L., Robinson, K. A., Gozu, A., Palacio, A., ... Cooper, L. A. (2005). Cultural competence: A systematic review of health care provider educational interventions. Medical Care, 43(4), 356-373.

Berlin, A., Nilsson, G., \& Törnkvist, L. (2010). Cultural competence among Swedish child health nurses after specific training: A randomized trial. Nursing \& Health Sciences, 12(3), 381-391.

Betancourt, J. R., Green, A. R., Carrillo, J. E., \& Ananeh-Firempong, O. (2003). Defining cultural competence: A practical framework for addressing racial/ ethnic disparities in health and health care. Public Health Reports, 118(4), 293-302.

Bonecutter, F. J., \& Gleeson, J. P. (1997). Broadening our view. Journal of Multicultural Social Work, 5(1-2), 99-119.

Chapman, R., Martin, C., \& Smith, T. (2014). Evaluation of staff cultural awareness before and after attending cultural awareness training in an Australian emergency department. International Emergency Nursing, 22(4), 179-184.

Clifford, A., McCalman, J., Bainbridge, R., \& Tsey, K. (2015). Interventions to improve cultural competency in health care for Indigenous peoples of Aus- 
tralia, New Zealand, Canada and the USA: A systematic review. International Journal for Quality in Health Care, 27(2), 89-98.

Gallagher, R. W., \& Polanin, J. R. (2015). A meta-analysis of educational interventions designed to enhance cultural competence in professional nurses and nursing students. Nurse Education Today, 35(2), 333-340.

Govere, L., \& Govere, E. M. (2016). How effective is cultural competence training of healthcare providers on improving patient satisfaction of minority groups? A systematic review of literature. Worldviews on Evidence-Based Nursing, 13(6), 402-410.

Horvat, L., Horey, D., Romios, P., \& Kis-Rigo, J. (2014). Cultural competence education for health professionals. Cochrane Database of Systematic Reviews. retrieved from https://doi.org/10.1002/14651858.CDo09405.pub2

Jongen, C., McCalman, J., \& Bainbridge, R. (2018). Health workforce cultural competency interventions: A systematic scoping review. BMC Health Services Research, 18(1), 232. Retrieved from https://doi.org/10.1186/s12913-018 $-3001-5$

Leininger, M. M. (1999). What is transcultural nursing and culturally competent care? Journal of Transcultural Nursing, 10(1), 9-9.

Leininger, M. M. (2002). The theory of culture care and the ethnonursing research method. In M. M. Leininger \& M. R. McFarland (Eds.), Transcultural nursing: Concepts, theories, research \& practice (3rd ed., pp. 71-116). New York, NY: McGraw-Hill.

Ličen, S., Karnjuš, I., \& Prosen, M. (2017). Ensuring equality through the acquisition of cultural competencies. In A. Petelin, N. Šarabon, \& B. Žvanut (Eds.), Health of the working-age population (p. 113). Koper, Slovenia: University of Primorska Press.

Lie, D. A., Lee-Rey, E., Gomez, A., Bereknyei, S., \& Braddock, C. H. (2011). Does cultural competency training of health professionals improve patient outcomes? Journal of General Internal Medicine, 26(3), 317-325.

Maier-Lorentz, M. M. (2008). Transcultural nursing: Its importance in nursing practice. Journal of Cultural Diversity, 15(1), 37-43.

Majumdar, B., Browne, G., Roberts, J., \& Carpio, B. (2004). Effects of cultural sensitivity training on health care provider attitudes and patient outcomes. Journal of Nursing Scholarship, 36(2), 161-166.

McElmurry, B. J., McCreary, L. L., Park, C. G., Ramos, L., Martinez, E., Parikh, R., ... Fogelfeld, L. (2009). Implementation, outcomes, and lessons learned from a collaborative primary health care program to improve diabetes care among urban Latino populations. Health Promotion Practice, 10(2), 293-302.

Moher, D., Liberati, A., Tetzlaff, J., Altman, D. G., \& PRISMA Group. (2009). Preferred reporting items for systematic reviews and meta-analyses: The PRISMA statement. PLoS Medicine, 6(7), e1000097. 
Paez, K. A., Allen, J. K., Carson, K. A., \& Cooper, L. A. (2008). Provider and clinic cultural competence in a primary care setting. Social Science \& Medicine, 66(5), 1204-1216.

Peña Dolhun, E., Muñoz, C., \& Grumbach, K. (2003). Cross-cultural education in U.S. medical schools: Development of an assessment tool. Academic Medicine, 78(6), 615-622.

Price, E. G., Beach, M. C., Gary, T. L., Robinson, K. A., Gozu, A., Palacio, A., ... Cooper, L. A. (2005). A systematic review of the methodological rigor of studies evaluating cultural competence training of health professionals. Academic Medicine, 80(6), 578-586.

Prosen, M. (2015). Introducing transcultural nursing education: implementation of transcultural nursing in the postgraduate nursing curriculum. Procedia: Social and Behavioral Sciences, 174, 149-155.

Sue, S., Zane, N., Nagayama Hall, G. C., \& Berger, L. K. (2009). The case for cultural competency in psychotherapeutic interventions. Annual Review of Psychology, 60, 525-548.

Truong, M., Paradies, Y., \& Priest, N. (2014). Interventions to improve cultural competency in healthcare: A systematic review of reviews. BMC Health Services Research, 14, 99. Retrieved from https://doi.org/10.1186/1472-6963-1499

Waite, R., \& Calamaro, C. J. (2010). Cultural competence: A systemic challenge to nursing education, knowledge exchange, and the knowledge development process. Perspectives in Psychiatric Care, 46(1), 74-80.

Warren, B. J. (2002). The interlocking paradigm of cultural competence: A best practice approach. Journal of the American Psychiatric Nurses Association, 8(6), 209-213.

S. Ličen, I. Karnjuš, \& M. Prosen (Eds.). (2019). Women, migrations and health: Ensuring transcultural healthcare (pp. 173-186).

Koper, Slovenia: University of Primorska Press.

https://doi.org/10.26493/978-961-7055-43-6.173-186 